1 Anonymous. Exercise for health. WHO/FIMS Committee on Physical Activity for Health. Bull World Health Organ 1995;733:135-6.

2 Pate RR, Pratt M, Blair SN, Haskell WL, Macera CA, Bouchard C, et al. Physical activity and public health: A recommendation from the Centers for Disease Control and Prevention and the American College of Sports Medicine. $\mathcal{F} A M A$ 1995;273:402-7

3 NIH Consensus development panel on physical activity and cardiovascular health. Physical activity and cardiovascular health. $¥ A M A$ 1996;276:241-6. 4 Killoran AJ, Fentem P, Caspersen CJ. Moving on. International perspectives on promoting phyical activity. London: Health Education Authority, 1994.

5 Anonymous. Recommendation no $R$ (95) 17 of the Committee of Ministers to the Member States on the significance of Sport for Society. Council of Europe. Strasbourg: CDDS (95) 58, 1995: 8-10.

6 US Physical activity and health; a report of the surgeon general. Atlanta GA: US Department of Health and Human Services, CDC, National Center for Disease Control and Prevention, USA, 1996.

7 Powell KE, Blair SN. The public health burden of sedentary living habits: theoretical but realistic estimates. Med Sci Sports Exerc 1994;26:851-6.

8 Ruwaard D, Kramers PGN, eds. Volksgezondheid Toekomst Verkenning. Den Haag: SDU, 1993.
9 Ruwaard D, Kramers PGN, eds. Volksgezondheid Toekomst Verkenning 1997. De som der delen. Utrecht: Elsevier/De Tijdstroom, 1997

10 Vuori I and Fentem P. Health, position paper. In: Vuori I, Fentem P, Svoboda B, Patriksson G, Andreff W, Weber W, eds. The significance of sport for society. Strasburg: Council of Europe Press, 1995: 11-90.

11 van Mechelen W. Can running injuries be effectively prevented? Sports Med 1995;19:161-5.

12 DiProchaska JO, Markus BH. The transtheoretical model: applications to exercise. In: Dishman RK, ed. Advances in exercise adherence. Champaign, Ill: Human Kinetics, 1994: 161-80.

13 Long BJ, Calfas KJ, Wooten W, Sallis JF, Patrick K, Goldstein M, et al. A multisite field test of the acceptability of physical activity counseling in primary care. Am f Prev Med 1996;12:73-81.

14 Calfas KJ, Long BJ, Sallis JF, Wooten W, Pratt M, Patrick K. A controlled trial of physician counselling to promote the adoption of phsyical activity. Prev Med 1996;25:225-33.

15 Stam PJA, Hildebrandt VH, Backx FJG, Velthuijsen JW. Sportief bewegen en gezondheidsaspecten: een verkennende studie naar kosten en baten. Amsterdam: SEO, 1996.

\title{
The United Kingdom Diploma in Sport and Exercise Medicine
}

On 15 September this year, the Academy of Medical Royal Colleges convened to consider, among other things, a draft proposal from the Intercollegiate Academic Board of Sport and Exercise Medicine. The board was quite specific about the inclusion of the word "exercise" in their proposal. This was accepted, putting in place the first diploma in sport medicine to be recognised throughout the United Kingdom and by all the medical Royal Colleges, ending what has been more than two years of arguing over who had the right to do what and with whom.

The first licensing body of medical graduates in the United Kingdom to offer a diploma in sports medicine was the Society of Apothecaries of London who had entry regulations in place as early as 1989. The Scottish Colleges (Surgeons and Physicians, Glasgow and Surgeons, Edinburgh and Physicians, Edinburgh) followed a year later. Of the two, the Society of Apothecaries had much the more stringent entry qualifications, demanding at least four years clinical practice and completion of a 20 week full time course in sports medicine or the equivalent part time course, or three full time courses of one weekend each together with two years full clinical sports medicine experience. Also acceptable was four years of full time sports medicine experience or a degree in sports medicine from a UK university.

By comparison, entry qualifications for the diploma Membership of the Royal College of Physicians UK, (a minimum of two and a half years postgraduate clinical experience of which at least 12 months must have been spent in the care of emergency medical patients, either adults or children, the latter post having been held within five years before the date of the examinations,) would seem to be less demanding.

Candidates for the UK Diploma in Sports Medicine must have engaged in the study of their profession for not less than two years after obtaining full registration with the General Medical Council and will be required to produce evidence of active participation in sports medicine.

These regulations may well change but it should not be assumed that the UK Diploma exam is any more easy (or difficult) than was the Apothecaries'. Indeed, any graduate who does not have at least three to four years "hands on" clinical experience in sports medicine and a Certificate of Advanced Life Support would be very unwise to present him or herself for examination. This comprises a two hour multiple choice and one hour short answer theoretical paper, followed by a practical examination to test core skills (such as cardiopulmonary resuscitation) to assess response to injury scenarios and first aid. Holders of other UK diplomas or degrees in sport and exercise medicine are likely to be exempt the first part of the exam, but all will be tested on their practical ability.

Other parties declaring an interest on the Intercollegiate Academic Board represent very diverse specialties. They include the following Royal Colleges; General Practitioners, Ophthalmologists, Paediatrics and Child Health, Pathologists, Physicians of London, Physicians of Edinburgh, Physicians and Surgeons of Glasgow, Surgeons of Edinburgh and Radiologists. Also represented are the Faculties of Dental Surgery, Occupational Medicine, and Public Health Medicine. Among all these, however, it must be said that those with the keenest clinical interest are the primary care doctors, physicians in clinical disciplines, and orthopaedic surgeons.

With training in sports medicine in the United States of America and Europe so well advanced, it is difficult to understand why the Colleges in England took so long to follow the Apothecaries' lead. Perhaps it was that they genuinely failed to realise the importance of sport and exercise in promoting the Health of the Nation. They certainly overlooked a lucrative source of income, because within months of the Diploma going live many of the professional sporting organisations in Britain were insisting that their medical officers in the field could show proof of training in sports medicine by producing their diplomas.

Setting up a UK Diploma has been only the first small step, the giant leap is going to be to establish specialist training because consultant physicians and orthopaedic surgeons with an additional specialist interest in sport and exercise medicine are going to form a very attractive acquisition for the cash starved NHS Trusts of the future. The Diploma has taken eight years to put in place, the question remains how many more years we are all going to have to wait for the CCST?

Chairman of Royal College of Physicians MARK HARRIES Consultant physician

Committee on Sport and Exercise Medicine 